June 1992

\title{
In Search of the Roots of Psychiatry
}

\author{
S. Nassir Ghaemi, M.D. \\ McLean Hospital, Belmont, Massachusetts
}

Follow this and additional works at: https://jdc.jefferson.edu/jeffjpsychiatry

Part of the Psychiatry Commons

Let us know how access to this document benefits you

\section{Recommended Citation}

Ghaemi, M.D., S. Nassir (1992) "In Search of the Roots of Psychiatry," Jefferson Journal of Psychiatry. Vol. 10 : Iss. 2 , Article 15.

DOI: https://doi.org/10.29046/JJP.010.2.012

Available at: https://jdc.jefferson.edu/jeffjpsychiatry/vol10/iss2/15

This Article is brought to you for free and open access by the Jefferson Digital Commons. The Jefferson Digital Commons is a service of Thomas Jefferson University's Center for Teaching and Learning (CTL). The Commons is a showcase for Jefferson books and journals, peer-reviewed scholarly publications, unique historical collections from the University archives, and teaching tools. The Jefferson Digital Commons allows researchers and interested readers anywhere in the world to learn about and keep up to date with Jefferson scholarship. This article has been accepted for inclusion in Jefferson Journal of Psychiatry by an authorized administrator of the Jefferson Digital Commons. For more information, please contact: JeffersonDigitalCommons@jefferson.edu. 


\title{
In Search of the Roots of Psychiatry
}

\author{
APPROACHES TO THE MIND: MOVEMENT OF THE PSYCHIATRIC SCHOOLS \\ FROM SECT TOWARD SCIENCE \\ Leston Havens, M.D. \\ Harvard University Press \\ Cambridge, Massachusetts \\ 1987, 399 pages, \$12, paperback.
}

\section{S. Nassir Ghaemi, M.D.}

Lewis Thomas called medicine the youngest science and psychiatry is arguably the youngest discipline of the youngest science. When a branch is new, its roots often reveal more than its fruits. And, in this book, Leston Havens, a professor of psychiatry at Harvard Medical School, goes in search of roots.

This book, originally published in 1973 and recently reissued, is long and full of historical details, making for sluggish reading. But when digested bit by bit, especially at the start of a residency, it can aid in organizing the morass of experiences termed psychiatry residency. Before reading Havens, psychiatric training seemed to me to consist of competing ideologies masquerading as common sense. Of course it made sense when my supervisor, a psychoanalyst, interpreted my psychotherapy cases in terms of relationship needs anchored in childhood. And of course it made sense when my inpatient supervisor, a psychopharmacologist, explained the importance of observing symptoms and signs for accurate diagnostic clarity in treating psychosis. And it even made sense when another psychotherapy supervisor surprised me with the statement that, after all, deep down there is no difference between us and our patients. But how to make sense of it all? How could I determine which approach made more sense, beyond simply deciding based on my own tastes? Then I encountered this book.

Havens reveals his own experience towards the end of his training. He describes how he had come under the influence of two brilliant teachers, equally charismatic, equally entrancing, and equally opposed in viewpoint. Many of his contemporaries were overwhelmed by one or the other man; Havens by both. And so he went backward in search of the roots of psychiatry, seeking to discover how such apparently perfect psychiatrists could be flawless in such opposing ways.

First, he outlines the objective-descriptive school, which comprises the "medical model" of psychiatry. It seeks to find the objective signs and symptoms of syndromes that can be classified into diseases with specific etiologies and specific treatments. Forerunners of this school in psychiatry are Emil Kraepelin, Jean-Martin Charcot, and the behaviorists. Second, he describes the psychoanalytic school, which seeks to 
determine the unconscious causes of symptoms and behaviors. By revealing these causes, it seeks to slowly transform the person's sense of self into a more functional integrated personality. Its founder was Freud, and its main exponents today are the object relations theorists. Third, he presents the interpersonal or social psychiatric school, which is the American contribution to these psychiatric schools. It seeks to locate the source of mental illness in the "Other," in the self in relation to the world around it, not in the isolated psyche or inside the brain. Its main proponent was Harry Stack Sullivan, and Havens does not hide his predilection for this school. Fourth, the existentialist school, which seeks to understand the feelings behind the symptoms and the experiences behind the illnesses. It is skeptical about any mental "illness" which cannot be interpreted as another human being's way of trying to cope with the universal vagaries of life. Its sources lie in Karl Jaspers and Ludwig Binswanger, and its recent partisans include R.D. Laing and Thomas Szasz. If the reader comes away from this broad outline of the origins of modern psychiatry with a sense of heightened interest, then he or she should read this book.

In my own experience, after encountering this historical schema, I was able to better classify and clarify my supervisors' conflicting messages. I no longer needed to either accept one and fight the others, or to try to water them down into some eclectic mixture, or to give up in frustration at all the confusion. In fact, Havens eschews all these options for a different approach. He advocates pluralism in psychiatry, a concept that is often misunderstood. As described by thinkers such as William James, pluralism is the belief in many types of truth, all equally valid, yet it does not mean anarchy of thought. Haven applies this meaning of pluralism to the psychiatric schools. In their purity, they each reveal a type of truth, a part of the reality of the human mind, but no one of them reveals it all.

What does this approach mean clinically? Havens implies that it may still be a matter of taste or temperament; we choose to concentrate on the approach with which we are most comfortable, but we would still benefit from recognizing that our approach is only one of many. Perhaps certain illnesses are particularly better suited to certain methods and Havens offers the following examples: paranoid patients may be best handled by interpersonal techniques; psychoses may be best examined by objective-descriptive procedures; and affective disorders may be best understood by psychoanalytic and existential methods. Over all, Havens advocates either selecting a best method for a particular illness, or selecting sequential methods for different stages of treatment of a particular illness. He opposes the eclectic combination of the schools into a kind of lowest common denominator, which sacrifices their higher achievements. In a time when the eclectic "biopsychosocial" paradigm is so easily accepted, Havens' pluralistic approach offers an appealing alternative.

Referring to the attempt of Louis Napoleon to restore the Empire of his uncle, Karl Marx once wrote that truly history repeats itself, but first as tragedy, then as farce. Leston Havens has written a systematic history of psychiatry. We should read it closely, lest we engage in a farcical repetition of the past. 